\title{
Article \\ Exploring the Influence of Social Media Usage for Academic Purposes Using a Partial Least Squares Approach
}

\author{
Jabar H. Yousif ${ }^{1, * \mathbb{C}}$, Firdouse R. Khan ${ }^{2}{ }^{\mathbb{D}}$, Safiya N. Al Jaradi ${ }^{3}$ and Aysha S. Alshibli ${ }^{1}$ \\ 1 Faculty of Computing and Information Technology, Sohar University, P.O. Box 44, Sohar PCI 311, Oman; \\ AAlshibli@su.edu.om \\ 2 Faculty of Business, Sohar University, P.O. Box 44, Sohar PCI 311, Oman; FKhan@su.edu.om \\ 3 Information Technology, University Technology \& Applied Science, P.O. Box 74, Sohar PCI 133, Oman; \\ safiya@act.edu.om \\ * Correspondence: jyousif@soharuni.edu.om; Tel.: +968-2672-0101-307
}

check for

updates

Citation: Yousif, J.H.; Khan, F.R.;

Al Jaradi, S.N.; Alshibli, A.S.

Exploring the Influence of Social

Media Usage for Academic Purposes

Using a Partial Least Squares

Approach. Computation 2021, 9, 64.

https://doi.org/10.3390/

computation 9060064

Academic Editor: Frank

Emmert-Streib

Received: 7 May 2021

Accepted: 26 May 2021

Published: 29 May 2021

Publisher's Note: MDPI stays neutral with regard to jurisdictional claims in published maps and institutional affiliations.

Copyright: (c) 2021 by the authors. Licensee MDPI, Basel, Switzerland. This article is an open access article distributed under the terms and conditions of the Creative Commons Attribution (CC BY) license (https:// creativecommons.org/licenses/by/ $4.0 /)$.

\begin{abstract}
Social media applications have been increasingly gaining significant attention from online education and training platforms. Social networking tools provide multiple advantages for communicating, exchanging opinions, and discussing specific issues. Social media also helps to improve the processes of teaching and learning through sharing educational programs. In this study, we used a quantitative research technique based on the partial least-squares (PLS) linear regression method to determine the influence of using social media as an online discussion and communication platform for academic purposes by assessing the relationships among the skills obtained through social media, the usage of social media, and the purpose of social media. A total of 200 students participated in this study ( $88 \%$ female and $12 \%$ males), and a purposive sampling technique was used to select a suitable population for the study. The results show that $61.5 \%$ of the participants use the web daily for more than five hours, mainly for social communication (meaningful dialog and discussion skills) and entertainment. The students agreed that social media develops their creative thinking, but it has no positive impact on their academic performance.
\end{abstract}

Keywords: numerical analysis; quantitative research; data-mining; social data; PLS-SEM approach

\section{Introduction}

Social media (SM) applications have gained significant attention in academia and practice; according to the annual reports of social media management platforms, social media and mobile apps achieved significant growth in usage in 2018. Throughout the Middle East, about 250 million people use 304.5 million mobile phones [1]. Social media has increasingly become a necessary tool for maintaining connections and transferring experiences globally. Emmert-Streib and Matthias examined incorporating big social data with social networks that needed to build accurate prediction models [2]. Emmert-Streib et al. described the importance of data from social media in a general context, which provides excellent opportunities for extensive mining amounts of text, image, and videobased data [3]. Statista has reported a steady increase in social media usage globally [4] and has recorded 2.82 billion users worldwide, which is expected to increase to 3.09 billion users, as shown in Figure 1.

Social networking tools provide multiple advantages for communicating, exchanging opinions, and discussing specific issues. Social media helps to improve the processes of teaching and learning by sharing educational programs. It helps to improve learning and distance learning methods, especially due to the divergence experienced during the COVID 19 pandemic. It also provides a platform for gaining experiences and analyzing and discussing different viewpoints on academic issues. It gives the possibility of creating unique rooms for training and exchanging study materials and useful links. 


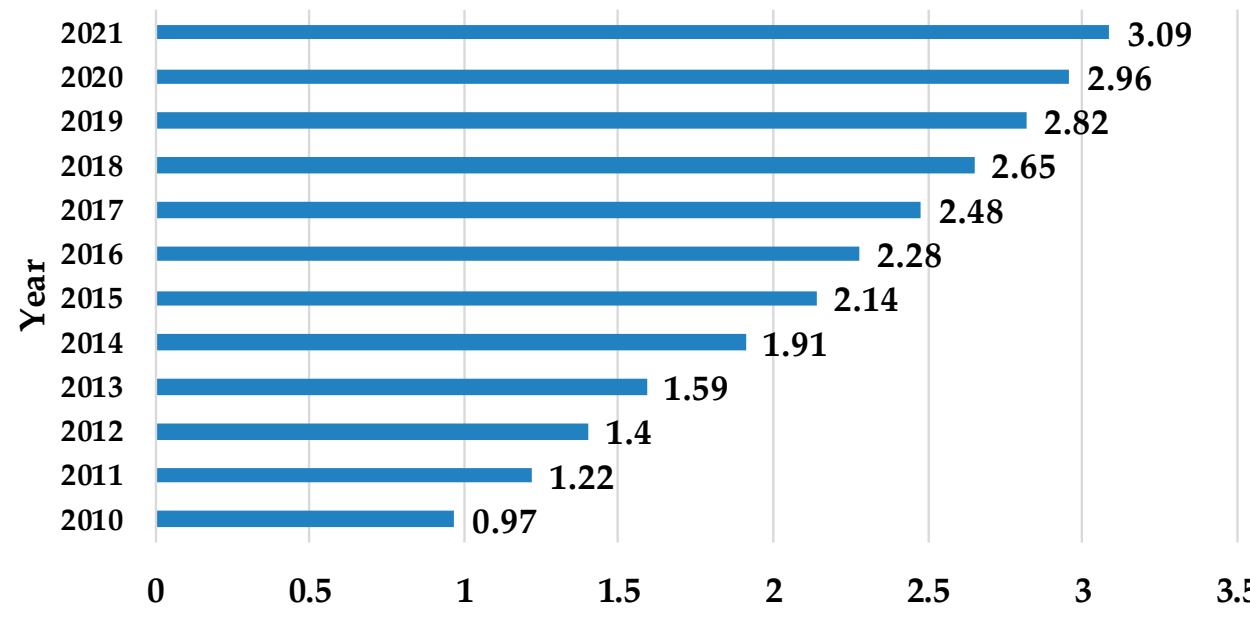

Annual No. of global Social Netw ork users ( Billion)

Figure 1. Annual number of global social network users (billion) 2010-2021 [1].

The distribution of social media users worldwide shows considerable variation in the number of users from one place to another, depending on the types of social sites and their features and support for different natural languages. Figure 2 illustrates that Facebook usage dominates in most Western countries, with 2.3 billion users, followed by YouTube with 1.9 billion users and WhatsApp with 1.5 billion users.

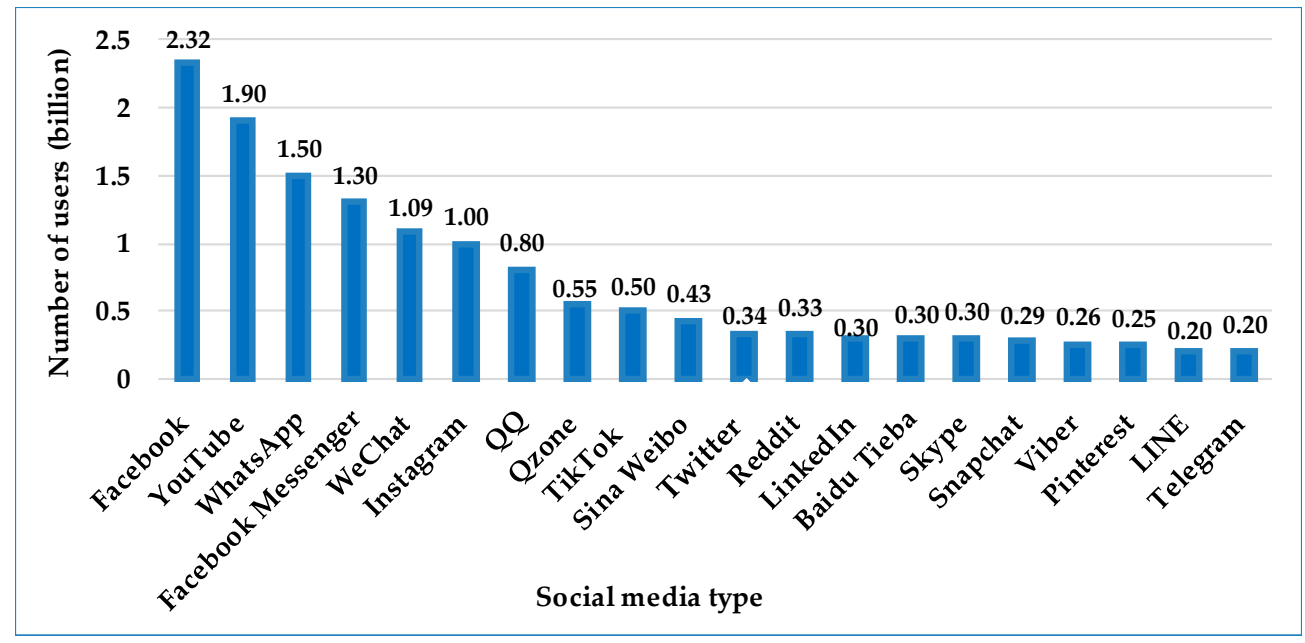

Figure 2. Globally distributed number of users using social media networks [4].

The recent reports indicate an increase of $11 \%$ in the number of social media users in Oman in 2021, reaching 4.14 million users [5]. Uddin M. found that addiction to social media affected mental health, and psychological disturbances could lead to anxiety, sleeping disorders, depression, and poor academic performances [6]. Al Rahmi and Othman concluded that social media facilitated students' educational experiences; however, if not controlled and time managed, it could negatively affect students' academic performances [7]. Nasrullah and Khan conducted a study in Saudi Arabia and revealed that social media did not support student learning. Students enjoyed meeting new friends online using social media, thereby spending too much of their time on such due to their online addiction [8]. El Khatib and Khan claimed that most Omani students used social networking (SN) for social purposes rather than academic purposes. The students diverted their attention to social communications, which caused lower academic achievements [9]. Therefore, a compelling reason for this study was to investigate using social networks. In this study, we deployed a quantitative research technique based on the linear regres- 
sion method to determine the influence of using social media as a communication and discussion channel for academic purposes by assessing the relationships among the skills obtained through social media, the usage of social media, and the purpose of social media.

\section{Literature Review}

The first part of the literature review focuses on the positive usage of social media. Chytas D. confirmed that most students used Facebook and YouTube channels for communicating and studying [10]. Hashim et al. found that most publications were available through social media networking, and most manuscripts focused on applying social media [11]. Al-Rahmi confirmed that using social media positively improved most students' performances [12]. Price et al. showed that using social media positively encouraged students to discuss and exchange information [13]. Bagarukayo E. confirmed that Facebook had a positive impact on students as a learning tool for assignment activities [14]. Alhaddad M. showed that students preferred social media platforms as a source for information [15]. Duke confirmed the possibility of using social media to discuss academic issues [16]. Bal E.B. claimed that social media contributed to increased understanding and ease of sharing information [17]. Tang confirmed that students used Twitter for sending subject-related materials and formative assessment activities, and therefore, Twitter in education promoted student interactions and learning content [18]. Rueda L. showed that there were highperforming students using social media but claimed that teachers using traditional teaching methods engaged their students more and, therefore, enhanced their performance [19]. Ali et al. showed a strong relationship between student learning performance and the satisfaction rate in information system courses using social media. The use of social media improved their academic performance, while traditional teaching methods allow instructors to engage more with students [20]. Benetoli et al. performed a comparison study, which indicated that $62 \%$ of participants agreed that social media positively improved their performance [21]. Kitching et al. claimed that students' communication skills improved by using healthcare programs with blogs, Twitter, and YouTube [22]. Van R. indicated that social media has made teaching more accessible and enjoyable and that students also supported social media technologies [23]. Eger L. stated that students felt that using Facebook was important for learning and identifying false information [24]. Dunn L. indicated that students believed that social media networks were very helpful and could increase their learning experience [25]. Junco et al. proved that social networking sites, such as Twitter, Wiki, and blogs, effectively enhanced students' academic performances. Junco claimed that students and academic staff were both interested in the learning process through Twitter instead of traditional learning. Therefore, it promoted social media as a suitable method for engaging students in their academic development [26]. Moran et al. indicated that social media sites had a significant impact on teaching and collaborative learning [27]. George and Dellasega showed that students preferred teachers who used social media as electronic resources in education, as it seemed to be very helpful in the medical curriculum [28]. Alshdefait et al. confirmed sustained use of social media by students as a helpful medium for the education and learning process at Jordanian public universities [29]. Sobaih et al. showed that social media had a significant impact on academic-related issues and, in particular, on teaching and learning [30]. Vollum M. analyzed social media usage in physical and health education and showed that social interaction positively influenced educational outcomes [31].

The other part of the literature review focuses on the requirements of using social media in education platforms. Wang et al. confirmed that only a very few students used social media to complete their assignments and experienced improvements [32]. Ghani and Hamid highlighted state-of-the-art social media big data analytical techniques and described the challenge of research problems in the field [33].

Willis and Exley proposed that using social media in the curriculum increased parents' engagement in student learning activities. However, teachers should have the essential substantive knowledge of language to inquire and contribute to social networking spaces 
online [34]. Carranza et al. suggested that there were advantages of using mobile learning to streamline the training process [35].

Table 1 presents the comparative study results of the literature survey for the period between 2011 and 2019.

Table 1. Comparative study results. 1, Facebook; 2, Twitter; 3, YouTube; 4, LinkedIn; 5, Instagram; 6, Snapchat; 7, Research gate; 8, WhatsApp; 9, SM-Others; 10, Comparison study and Survey; 11, Questionnaire; 12, Interview; 13, Methods-Others.

\begin{tabular}{|c|c|c|c|c|c|c|c|c|c|c|c|c|c|c|}
\hline \multirow{2}{*}{ Reference/Year } & \multicolumn{9}{|c|}{ Type of Social Media } & \multicolumn{4}{|c|}{ Method } & \multirow[t]{2}{*}{ Findings } \\
\hline & 1 & 2 & 3 & 4 & 5 & 6 & 7 & 8 & 9 & 10 & 11 & 12 & 13 & \\
\hline Chytas, 2019 [10] & $x$ & $X$ & $x$ & & & & & & & $x$ & & & & $\begin{array}{l}84 \% \text { supported using Facebook, and } 86 \% \text { supported using } \\
\text { YouTube in the teaching environment }\end{array}$ \\
\hline Hashim, 2018 [11] & $x$ & $x$ & $x$ & & & & & $x$ & $x$ & $x$ & & & $x$ & $\begin{array}{c}\text { Comparison study of published papers over ten years } \\
\text { (2008-2018); } 85 \% \text { of the publications were published as journal } \\
\text { articles, 30\% focused on social media in general, and } 70 \% \text { focused } \\
\text { on specific applications, including } 23 \% \text { Twitter, } 20 \% \text { Facebook, } \\
10 \% \text { weblogs, } 9 \% \text { YouTube, 3\% WhatsApp, and } 40 \% \text { adopted } \\
\text { quantitative research; } 10 \% \text { of the research papers utilized a } \\
\text { mixed-method }\end{array}$ \\
\hline Al-Rahmi et al. 2018 [12] & $x$ & $x$ & & $x$ & & & $x$ & & $x$ & & $x$ & & & $95 \%$ supported using social media for education and participation \\
\hline Price et al. 2018 [13] & & $x$ & & & & & & & $x$ & $x$ & & & & $81 \%$ supported using Twitter in teaching nursing courses \\
\hline Bagarukayo, 2018 [14] & $x$ & & & & & & & & & & $\mathrm{X}$ & & & $\begin{array}{c}\text { Questionnaire to explore using Facebook as a facilitated tool in } \\
\text { teaching; } 26.8 \% \text { strongly agreed, and } 44.4 \% \text { agreed; however, } \\
16.7 \% \text { were neutral, and } 12.1 \% \text { did not agree or } \\
\text { strongly disagreed. }\end{array}$ \\
\hline Alhaddad, 2018 [15] & $x$ & $x$ & $x$ & & $x$ & $x$ & & $x$ & & & $x$ & & & $90 \%$ supported using social media networking in medical studies \\
\hline Duke et al. 2017 [16] & $x$ & & $x$ & & & & & & & & $x$ & & & $96 \%$ supported using social media to discuss academic problems \\
\hline Bal Erkan, 2017 [17] & $\mathrm{X}$ & $\mathrm{X}$ & $x$ & & & & & & & & $\mathrm{X}$ & & & $\begin{array}{l}83 \% \text { mentioned that using social media was an effective } \\
\text { learning tool }\end{array}$ \\
\hline Tang, 2017 [18] & & $x$ & & & & & & & & $x$ & & & & $\begin{array}{c}\text { Examined } 51 \text { research papers and showed positive attitudes } \\
\text { related to using Twitter in education; } 56.8 \% \text { used Twitter for } \\
\text { subject-related materials, } 33.3 \% \text { used Twitter for formative } \\
\text { assessment activities, and } 90 \% \text { of research work was } \\
\text { implemented in the higher education field }\end{array}$ \\
\hline Rueda, 2017 [19] & $x$ & $x$ & & $x$ & & & & & $x$ & $x$ & $x$ & & & $\begin{array}{l}156 \text { students participated in the questionnaire; } 90 \% \text { of students } \\
\text { regularly attended the classes, a strong relationship between } \\
\text { student performance and satisfaction rate in information system } \\
\text { courses using social media }\end{array}$ \\
\hline Ali, 2017 [20] & $x$ & & $x$ & & & & & $x$ & $x$ & & & $x$ & & $\begin{array}{l}62 \% \text { agreed, } 23 \% \text { disagreed, and } 15 \% \text { were not sure that social } \\
\text { media positively improved the performance of students }\end{array}$ \\
\hline Benetoli, 2015 [21] & $x$ & $x$ & & & & & & & $x$ & $x$ & & & & $\begin{array}{c}\text { Twenty-four studies were included in this study based on } \\
\text { inclusion criteria; the results showed that } 78.5 \% \text { of studies used } \\
\text { specific social media tools in teaching pharmacy courses, and } \\
58.3 \% \text { of studies implemented social media sites, such as Twitter, } \\
\text { Wiki, and blogs }\end{array}$ \\
\hline Kitching, 2015 [22] & & $x$ & $x$ & & & & & & $x$ & & & $x$ & & $\begin{array}{l}\text { Twelve staff participated in this study (in the healthcare sector } \\
\text { from } 11 \text { organizations); most participants were cautioned about } \\
\text { using social media in education }\end{array}$ \\
\hline Van Rooyen, 2015 [23] & & & & & & & & & & & $x$ & $x$ & & $\begin{array}{c}94 \% \text { supported using social media technologies; } 93.63 \% \text { indicated } \\
\text { that using social media made teaching more accessible } \\
\text { and enjoyable }\end{array}$ \\
\hline Eger, 2015 [24] & $x$ & & & & & & & & & $x$ & & & & $\begin{array}{l}77 \% \text { used Facebook to improve their knowledge; } 9 \% \text { stated that } \\
\text { they had not joined any study group on social media }\end{array}$ \\
\hline Dunn, 2013 [25] & $x$ & $x$ & & & & & & & $x$ & $x$ & & & $x$ & $\begin{array}{c}68 \% \text { believed that social media could improve the learning } \\
\text { activity, } 22 \% \text { of participants disagreed, } 10 \% \text { of them were unsure; } \\
\text { the experimental group results showed that } 75 \% \text { indicated using } \\
\text { social media networks was very helpful, and } 18 \% \text { admitted it was } \\
\text { helpful; however, } 7 \% \text { specified it as slightly helpful }\end{array}$ \\
\hline Junco, 2011 [26] & & $X$ & & & & & & & & $x$ & & & & $\begin{array}{l}48.20 \% \text { indicated that Twitter could enhance } \\
\text { academic development. }\end{array}$ \\
\hline Moran, 2011 [27] & $x$ & $x$ & $x$ & $x$ & & & & & $x$ & $x$ & & & & $\begin{array}{l}40 \% \text { of faculty members asked students to use social media } \\
\text { networks to read and solve assignments }\end{array}$ \\
\hline George, 2011 [28] & & $x$ & $x$ & & & & & & $x$ & $x$ & & $x$ & & $\begin{array}{c}\text { Students rated the quality of teaching through social media as } 4.8 \\
\text { out of } 5 \text {; the rate of using social media as electronic resources in } \\
\text { medical schools was } 4.7 \text { out of } 5\end{array}$ \\
\hline Wang, 2011 [32] & $x$ & $x$ & $x$ & $x$ & & & & & $x$ & & $x$ & & & $\begin{array}{l}20 \% \text { of students used social media to solve their assignments, } \\
\text { which contributed to their achievements }\end{array}$ \\
\hline
\end{tabular}




\section{Data and Methods}

\subsection{Data}

Table 2 presents the results of respondents' descriptive demographic information. The data for this study were collected through a printed questionnaire that was provided to individual undergraduate students at different universities in Oman. The data collection period was two weeks. The students permitted us to use their responses in this study provided we did not publish personal information such as names, emails, or mobile numbers. The participants were given a training session to explain the study's aims and provide instructions on filling out the questionnaire. A purposive sampling technique was implemented to select a suitable population for the study. Therefore, 250 questionnaires were distributed, and only 200 students (176 females and 24 males) were selected. Each student answered the questions honestly according to his/her opinion. A total of 85 students were between the age of 16 and 19, and 114 students were between 20 and 29. One student was aged more than 30 years old. The social media sites included in this study were Instagram, Facebook, WhatsApp, Twitter, Snapchat, Pinterest, YouTube, LinkedIn, Google+, and Tumblr.

Table 2. Respondents' descriptive statistical, demographic information.

\begin{tabular}{cccc}
\hline Characteristics & & Frequency & Percent \% \\
\hline \multirow{2}{*}{ Gender } & No. of males & 24 & 12.0 \\
& No. of females & 176 & 88.0 \\
Age & 16 to $<20$ years old & 85 & 42.5 \\
& 20 to $<30$ years old & 114 & 57.0 \\
& 30 years and above & 1 & 0.5 \\
\hline \multirow{2}{*}{ Educational qualification } & Primary & 4 & 0.5 \\
& Secondary & 1 & 97.5 \\
\hline \multirow{2}{*}{ Daily usage of social media } & 1 to $<3 \mathrm{~h}$ & 195 & 15.0 \\
& 3 to $<5 \mathrm{~h}$ & 30 & 23.5 \\
& 5 to $<7 \mathrm{~h}$ & 62 & 31.0 \\
\hline
\end{tabular}

Source, questionnaire.

\subsection{Research Methodology}

In this study, we used a quantitative research technique based on partial least-squares (PLS) linear regression to determine the influence of using social media as a communication and discussion channel for academic purposes by assessing the relationships among the skills obtained through social media, the usage of social media, and the purpose of social media. A purposive sampling technique was used to select suitable participants for the study.

The research hypotheses were as follows:

Hypothesis 1 (H1). The purpose of social media influences the skills obtained through social media.

Hypothesis 2 (H2). The purpose of social media influences the usage of social media.

\subsection{Partial Least Squares Method (PLS)}

Partial least-squares (PLS) is a statistical method that finds a linear regression model by projecting the predicted variables and the explanatory variables to a new space. Therefore, it is sometimes called a "projection to latent structures". PLS requires that standardize latent variable scores have a mean value of 0 and a standard deviation value of 1 . The latent variable approach is used to model the covariance structures in the two spaces (predicted and experimental variables). The main advantage of PLS is the ability to model multiple 
dependent and independent variables. The PLS algorithm was proposed by Lohmöller, in 1989, including three stages [36,37], as presented in Algorithm 1.

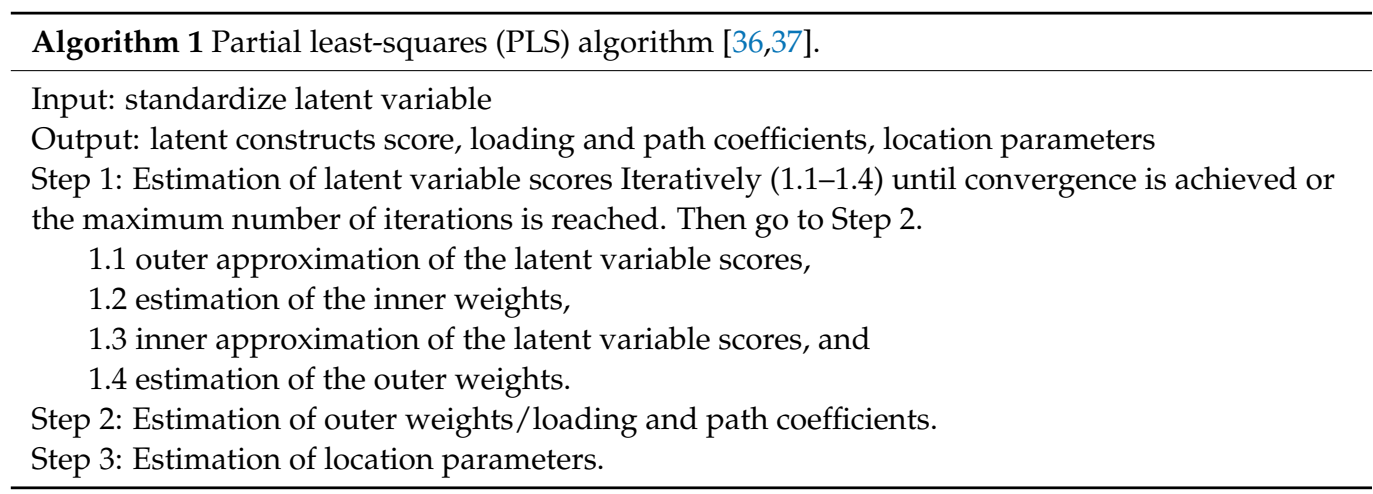

\section{Results and Discussion}

Table 2 presents the respondents' descriptive statistical, demographic information.

The current study considers factors such as skills obtained through social media, the usage of social media, and the purpose of social media. Details of the factors (latent variables) and subfactors (apparent variables) are presented in Table 3.

Table 3. Details of the latent and apparent variables.

\begin{tabular}{|c|c|c|}
\hline Factors (Latent Variables) & & Subfactors (Apparent Variables) \\
\hline \multirow{5}{*}{$\begin{array}{l}\text { Skills obtained through } \\
\text { social media }\end{array}$} & s1 & $\begin{array}{l}\text { Social media helps students improve their } \\
\text { communication skills }\end{array}$ \\
\hline & s2 & Using social media, students' scientific level increases \\
\hline & s3 & Social media develops students' creative thinking \\
\hline & s4 & $\begin{array}{l}\text { Social media develops meaningful dialog and } \\
\text { discussion skills }\end{array}$ \\
\hline & s5 & Social media affects the students' social skills \\
\hline \multirow{5}{*}{ Usage of social media } & $\mathrm{u} 1$ & I use social media for educational purposes \\
\hline & $\mathrm{u} 2$ & Social media offers diversified educational experiences \\
\hline & u3 & Social media offers lectures outside of study time \\
\hline & $\mathrm{u} 4$ & $\begin{array}{l}\text { Social media maintains the confidentiality of } \\
\text { user information }\end{array}$ \\
\hline & u5 & $\begin{array}{c}\text { The use of social media has become a necessity because } \\
\text { it shortens the effort and time }\end{array}$ \\
\hline \multirow{4}{*}{ Purpose of social media } & p1 & I use social media for entertainment purpose \\
\hline & p2 & I use social media for study purposes \\
\hline & p3 & I used social media mainly for social communications \\
\hline & $\mathrm{p} 4$ & I use social media for trade and labor \\
\hline
\end{tabular}

The measurement model is used to test the latent variables and the apparent variables, as shown in the conceptual model in Figure 3. The variables used include the skills obtained through social media, the usage of social media, and the purpose of social media. 


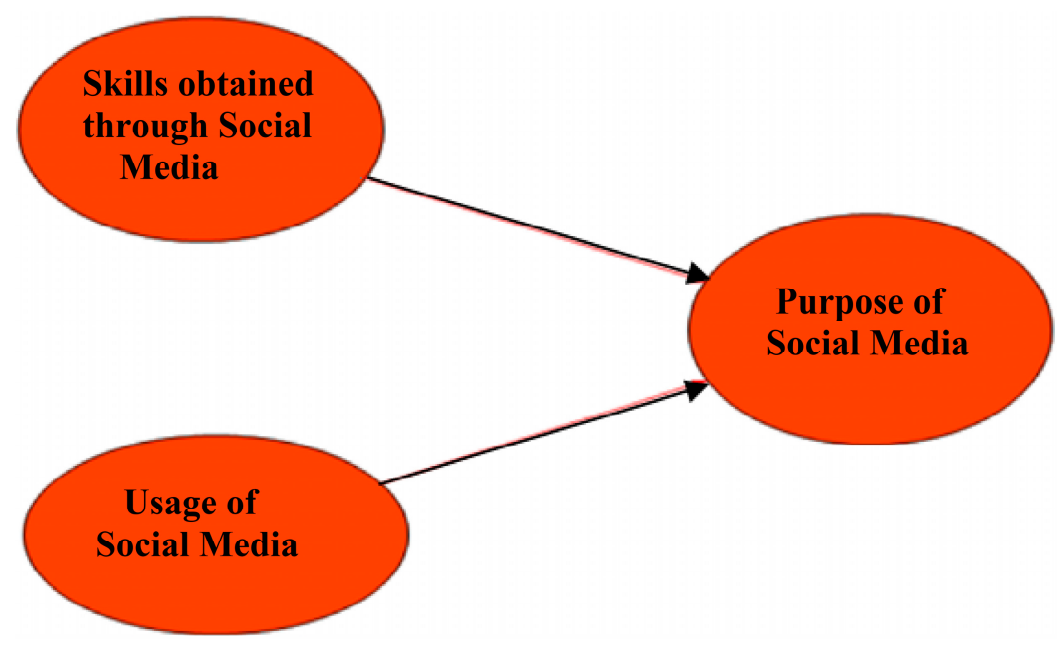

Figure 3. Conceptual model for assessing the relationships among the skills obtained through social media, the usage of social media, and the purpose of social media.

\subsection{Measurement Model}

The relationships were shown among the skills obtained through social media, the usage of social media, and the purpose of social media. The reliability of the model was tested based on validating the discriminant and convergent results [38]. Figure 4 shows the initial path model coefficients and the values of the variables (the skills obtained through social media, the usage of social media, and the purpose of social media).

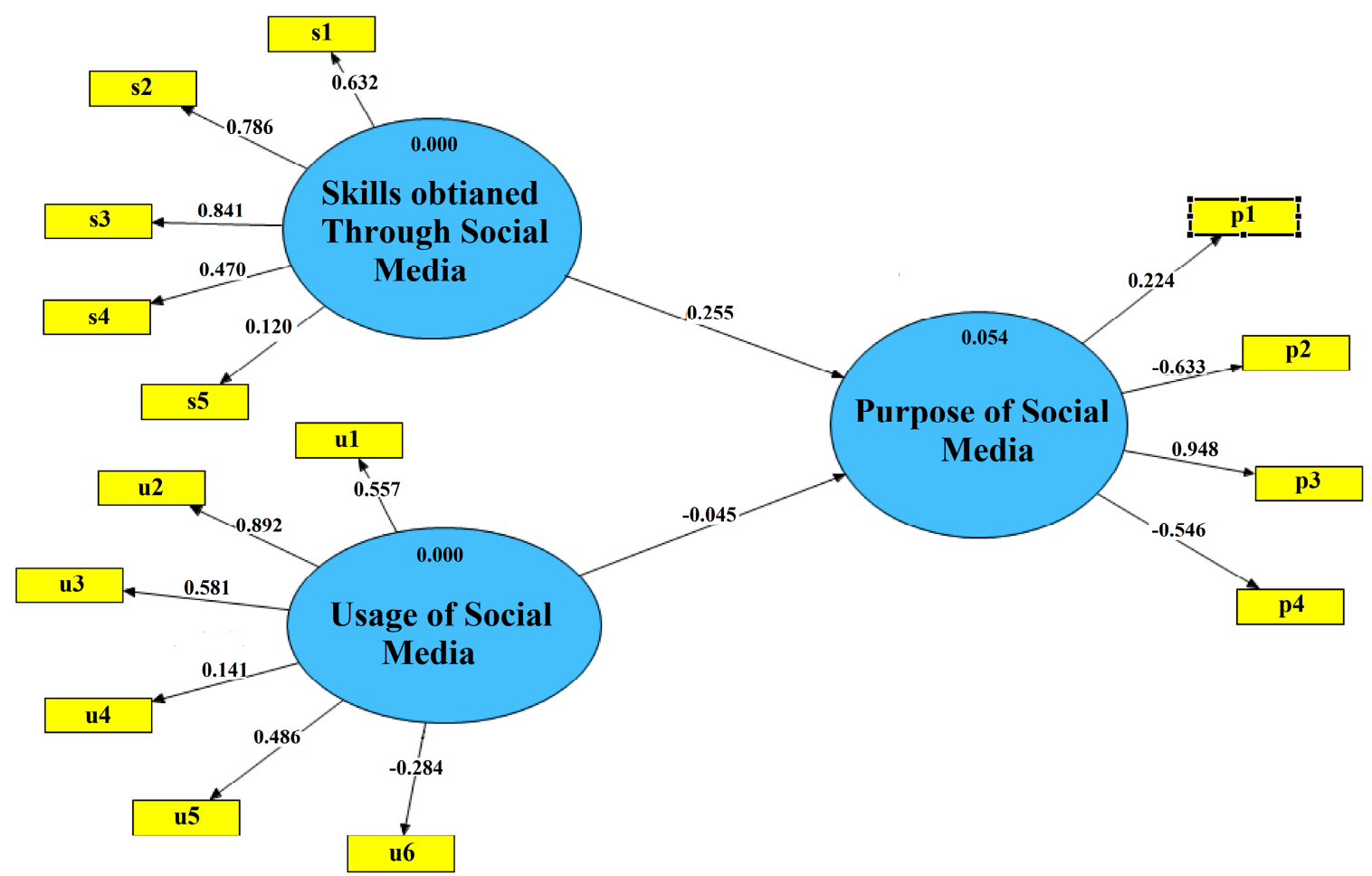

Figure 4. Initial path model coefficients and the values of the variables (s1-s5 skills obtained through social media; $\mathrm{u} 1-\mathrm{u} 6$ the usage of social media; p1-p4 the purpose of social media).

\subsection{Model Reliability}

Composite reliability is used to validate the construct reliability results and inner consistency values, which is more suitable than Cronbach's alpha. Hair et al. determined the least score value of composite reliability should be 0.7 , and the Cronbach's alpha 
minimum score should be 0.6 [39]. The measurement model reliability was validated based on subfactor and factor loading reliability. A score of 0.45 for the subfactors' loading is preferable [40]. The scores of subfactor loadings are examined, and any variable with a score greater than 0.50 is accepted [41], and any subfactors with low loading scores are removed from the final model, as shown in Figure 5. In addition, Table 4 presents the latent construct scores of composite reliability, factor loadings, and Cronbach's alpha, which were achieved using the PLS algorithms. The results show the proposed model can be reliable because Cronbach's alpha score is above 0.437 , and the score of composite reliability is greater than 0.621 .

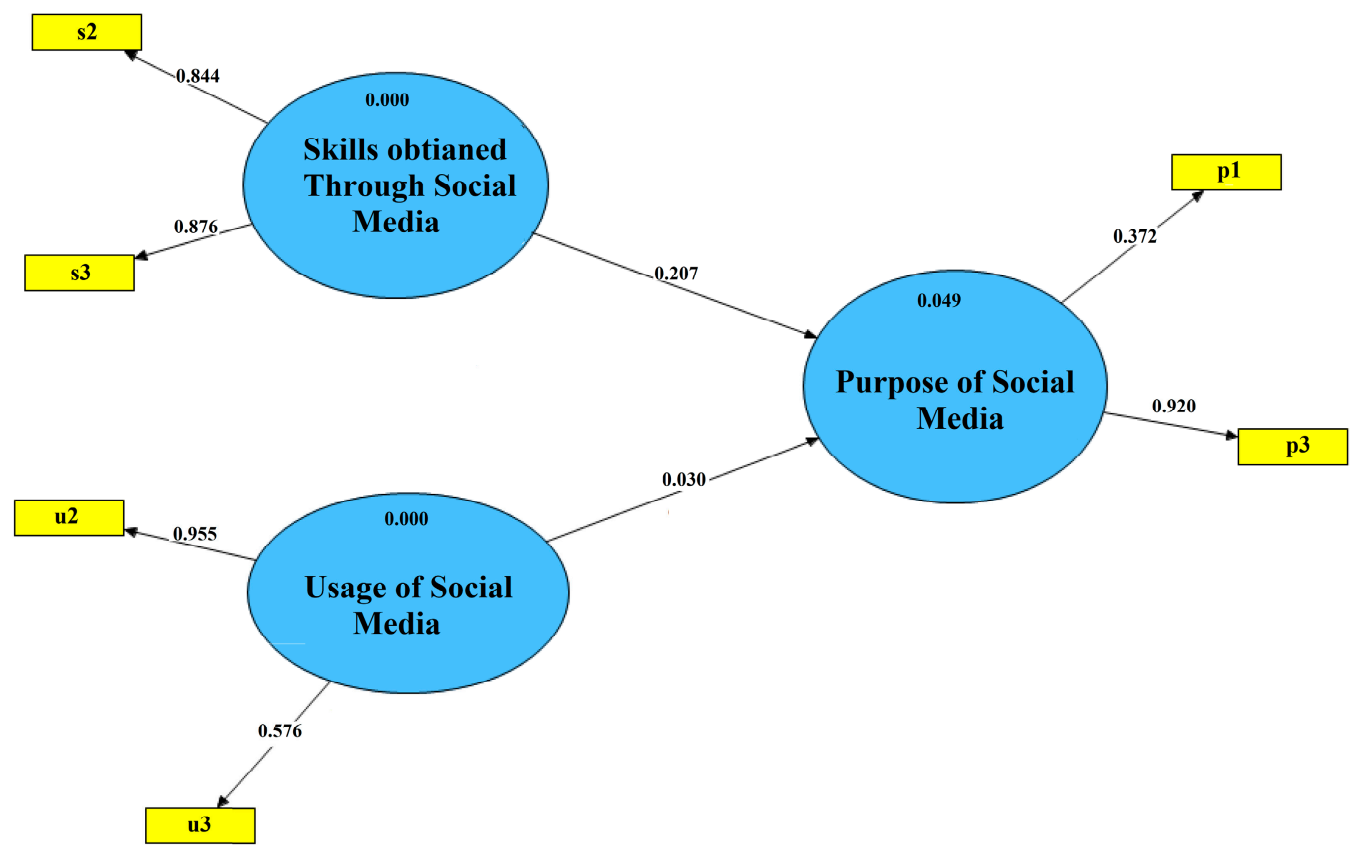

Figure 5. Final path model after removing the least significant variables.

Table 4. Indicators of latent constructs score.

\begin{tabular}{|c|c|c|c|c|c|}
\hline & Factors and Subfactors & Factor Loading & Cronbach's Alpha & $\begin{array}{l}\text { Composite } \\
\text { Reliability }\end{array}$ & AVE \\
\hline $\mathrm{P}$ & Purpose of Social Media & & 0.437012 & 0.621947 & 0.492445 \\
\hline p1 & I use social media for entertainment purpose & 0.372376 & & & \\
\hline p3 & I used social media mainly for social communication & 0.919905 & & & \\
\hline S & Skills obtained through Social Media & & 0.649058 & 0.850378 & 0.739767 \\
\hline s3 & Social media develops students' creative thinking & 0.844226 & & & \\
\hline s4 & $\begin{array}{l}\text { Social media develops meaningful dialog and } \\
\text { discussion skills }\end{array}$ & 0.87568 & & & \\
\hline $\mathrm{U}$ & Usage of Social Media & & 0.472086 & 0.756344 & 0.622276 \\
\hline u3 & Social media offers lectures outside of study time & 0.955464 & & & \\
\hline $\mathrm{u} 4$ & $\begin{array}{l}\text { Social media maintains the confidentiality of } \\
\text { user information }\end{array}$ & 0.575882 & & & \\
\hline
\end{tabular}

\subsection{Convergent Validity}

To verify the convergent validity of the proposed model, the following two conditions were required:

(a) Achieve a score greater than or equal to 0.7 for the outer loadings. 
(b) Ensure that the score of average variance extracted (AVE) for all latent variables is more than 0.50 [42]. A score of 0.4 is adequate [43] with the condition that the composite reliability score is more than 0.6 [44]. Table 4 shows that the convergent validity is acceptable based on the obtained variance extracted score ranging from 0.492 to 0.739. Discriminant validity should evidence that the construct (latent variable) in the PLS path model has the most robust relationship score as compared with other construct variables. Table 5 shows that the obtained results of the square root of AVE and constructs correlation score were in the accepted ranges, which indicates a satisfactory discriminant validity for constructs.

Table 5. Discriminant validity results.

\begin{tabular}{cccc}
\hline & $\begin{array}{c}\text { Purpose of Social } \\
\text { Media }\end{array}$ & $\begin{array}{c}\text { Skills Obtained through } \\
\text { Social Media }\end{array}$ & $\begin{array}{c}\text { Usage of } \\
\text { SOCIAL Media }\end{array}$ \\
\hline Purpose of social media & 1 & & \\
\hline $\begin{array}{c}\text { Skills obtained through } \\
\text { social media }\end{array}$ & 0.219999 & 1 & 1 \\
\hline Usage of social media & 0.119495 & 0.433187 & \\
\hline
\end{tabular}

\subsection{Structural Model Analysis}

The PLS bootstrapping test is used to determine the R-squared results of independent and dependent variables, in addition to path coefficient values, which are shown in Table 6 and illustrates in Figure 6.

Table 6. Bootstrap values and T-values of path coefficients.

\begin{tabular}{cccccc}
\hline \multicolumn{1}{c}{ Factors } & $\begin{array}{c}\text { Original } \\
\text { Sample (O) }\end{array}$ & $\begin{array}{c}\text { Sample Mean } \\
(\mathbf{M})\end{array}$ & $\begin{array}{c}\text { Standard } \\
\text { Deviation } \\
\text { (STDEV) }\end{array}$ & $\begin{array}{c}\text { Standard } \\
\text { Error (STERR) }\end{array}$ & $\begin{array}{c}\text { T Statistics } \\
\text { (IO/STERR I) }\end{array}$ \\
\hline $\begin{array}{l}\text { Supported } \\
\text { Skills obtained through } \\
\text { social media }>\text { purpose } \\
\text { of social media }\end{array}$ & 0.207098 & 0.203789 & 0.09044 & 0.09044 & 2.289899 \\
\hline $\begin{array}{l}\text { Usage of social media }> \\
\text { purpose of social media }\end{array}$ & 0.029783 & 0.081326 & 0.119063 & 0.119063 & 0.250144 \\
\hline
\end{tabular}

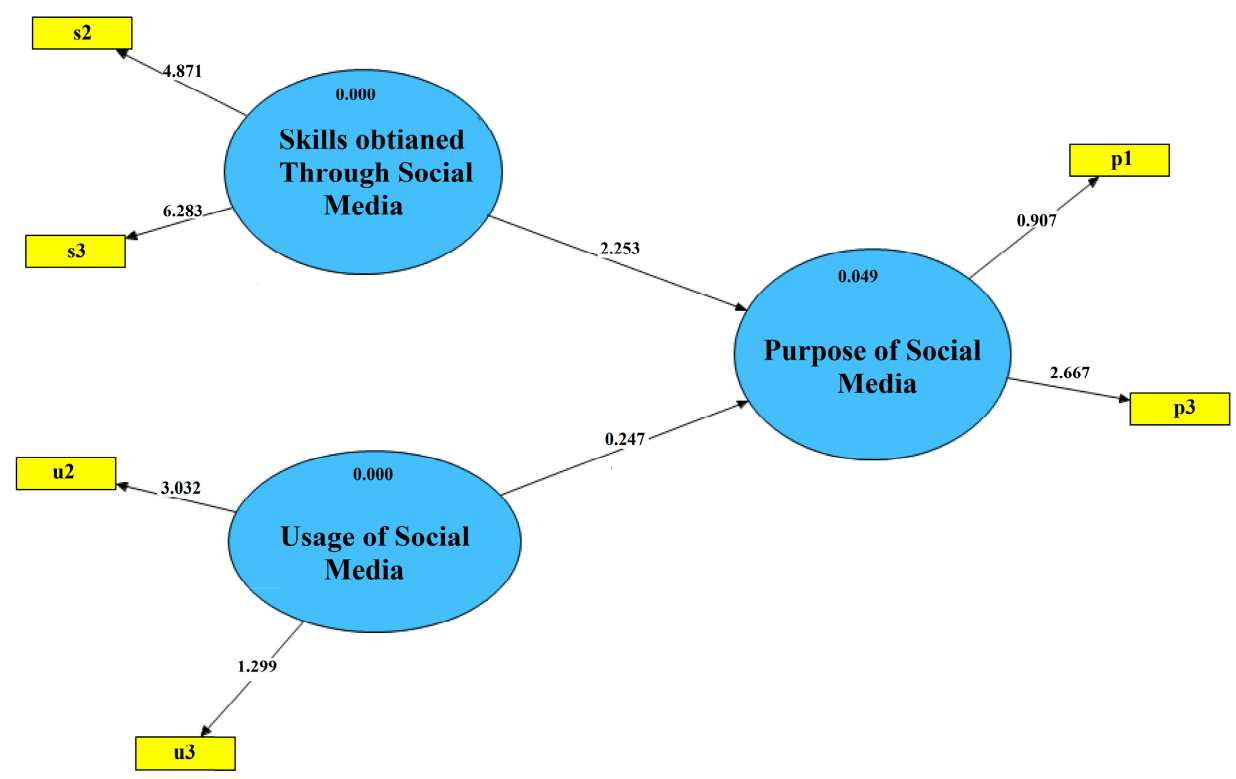

Figure 6. Values of selected variables after implement the PLS bootstrap method. 
Equation (1) determines the goodness-of-fit (GOF) value, which is the overall model fit for PLSEM as follows:

$$
\mathrm{GOF}=\sqrt{ } \text { average } \mathrm{R}^{2} \times \text { average communality }
$$

Table 7 presents that the GOF of the proposed model is equal to $\sqrt{ } 0.04912 \times 0.618163$ $=0.174253$.

Table 7. Model evaluation results.

\begin{tabular}{cccccc}
\hline Factors & $\mathbf{R}^{\mathbf{2}}$ & Communality & $\mathbf{H}^{\mathbf{2}}$ & Redundancy & $\mathbf{F}^{\mathbf{2}}$ \\
\hline Purpose of social media & 0.04912 & 0.492445 & -0.01 & 0.023786 & -0.122 \\
\hline $\begin{array}{c}\text { Skills obtained through } \\
\text { social media }\end{array}$ & 0.739767 & 0.229 & & 0.229 \\
\hline Usage of social media & 0.622277 & -0.022 & & -0.022 \\
\hline Average & 0.04912 & 0.618163 & 0.017 & 0.454 & 0.316 \\
\hline $\begin{array}{r}\text { GOF = square-root (average } \mathrm{R}^{2} \times \text { average communality) }=\sqrt{ } 0.04912 \times 0.618163=0.174253, \mathrm{H}^{2} \text { is } \\
\text { CV-communality index and } \mathrm{F}^{2} \text { is CV-redundancy index }\end{array}$ \\
\hline
\end{tabular}

The path coefficient $\beta$ is tested based on the obtained structural model and hypothesis, as PLS does not require normally distributed data. However, the latent dependent variables are evaluated using $R^{2}$ and the average variance. The construct's percent variation of the model is measured using $R^{2}$ [45]. The model has a predictive significance if the $R^{2}$ score is greater than zero, and a score less than 0 indicates a predictive insignificance model, as shown in Figure 7.

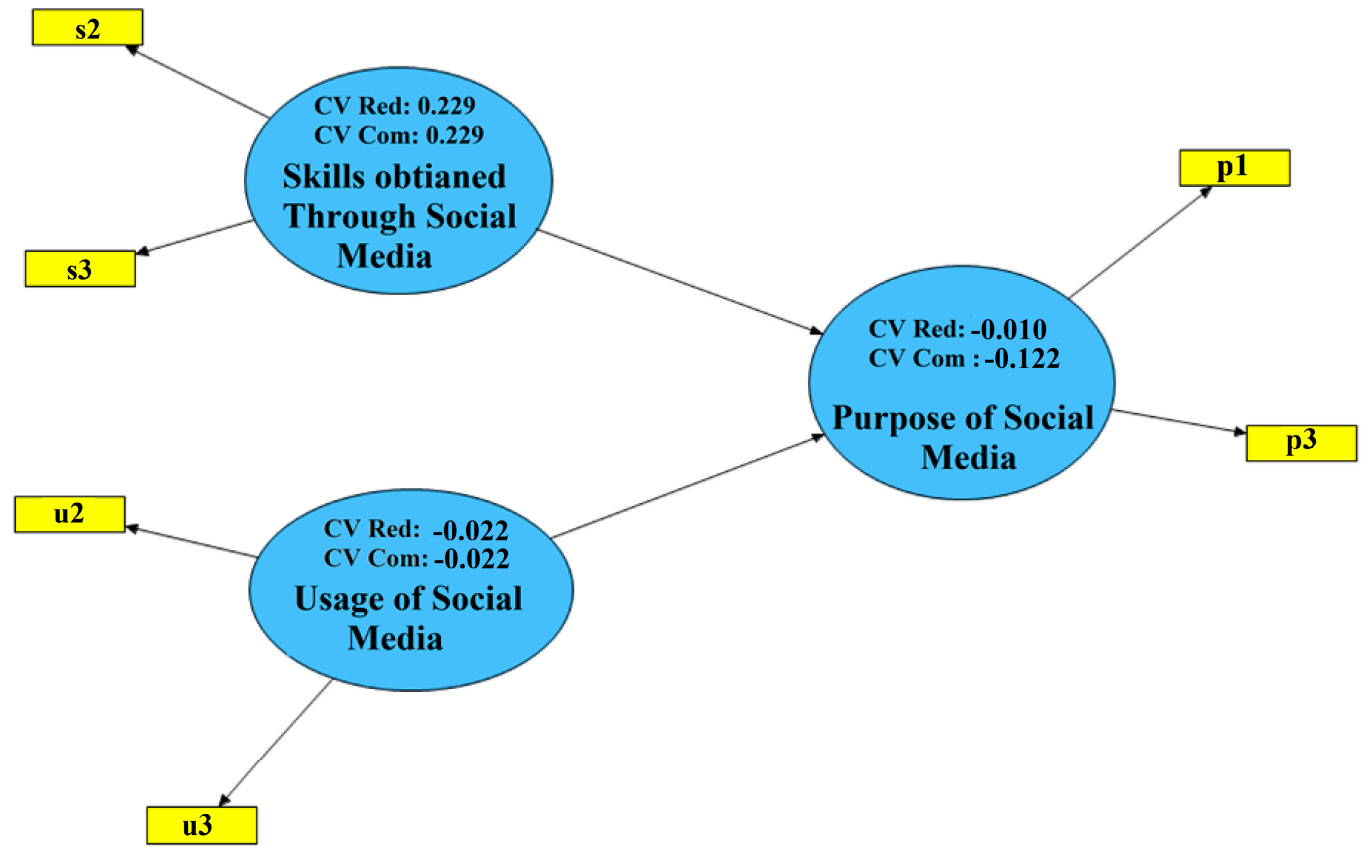

Figure 7. Blindfolding evaluation procedure for validating the predictive accuracy of the model.

\section{Conclusions}

Many studies have examined the purpose of using social media for teaching and training in academic platforms and have shown that social media does not support students' learning and that its use should be controlled and time managed to prevent adverse effects on students' academic performance. Therefore, in this study, we investigated the influence of using social media as a communication and discussion channel for educational purposes 
by assessing the relationship between the skills obtained through social media and using social media and the purpose of social media. We used a quantitative research technique based on the linear regression method to examine and investigate the influence of using social media as a discussion and communication platform for academic purposes. A total of 200 participants, including 195 undergraduate students from various Omani universities, participated in this study ( $88 \%$ female and $12 \%$ males). $61.5 \%$ of the student respondents reported using the web daily for more than $5 \mathrm{~h}$ and mainly for social dialog communication and entertainment purposes. The students agreed that social media develops their creative thinking, but it has no positive impact on their academic performance. The conceptual model reliability was validated based on subfactor loading with a score of 0.45 . The result of the mathematical PLS model based on Cronbach's alpha score (0.437) was valid, and the composite reliability was greater than 0.621 . This means that the students were more focused on the skills they obtained through social media than the purpose of social media as a communication and discussion channel, and they did not focus on enhancing academic performance.

The following are some suggestions for increasing students' engagement and interests:

(a) Encourage students to use social media for academic purposes and practice;

(b) Encourage teachers to create and monitor special classes for engaging students in discussions and presentations;

(c) Create free space for dialogue between students and exchanging views regarding solving school assignments;

(d) Closely monitor and direct the students to use social media positively as flipped classrooms;

(e) Restrict the students from wasting their time indulging in unproductive chat purposes;

(f) Raise awareness of the risks involved in using social media platforms (due to security concerns) rather than curtailing them.

Author Contributions: Conceptualization, J.H.Y. and F.R.K.; methodology, J.H.Y. and F.R.K.; software, S.N.A.J.; validation, J.H.Y. and F.R.K.; formal analysis, F.R.K.; investigation, S.N.A.J.; resources, A.S.A.; data curation, S.N.A.J. and A.S.A.; writing_original draft preparation, J.H.Y.; writingreview and editing, F.R.K. and A.S.A.; visualization, S.N.A.J. All authors have read and agreed to the published version of the manuscript.

Funding: This research received no external funding.

Conflicts of Interest: The authors declare no conflict of interest.

\section{References}

1. Statista. Comparison of Global and Middle Eastern Internet Penetration Rate. 2019. Available online: https://www.statista.com/ statistics/265171/comparison-of-global-and-middle-eastern-internet-penetration-rate/ (accessed on 25 January 2021).

2. Emmert-Streib, F.; Dehmer, M. Data-driven computational social network science: Predictive and inferential models for Webenabled scientific discoveries. Front. Big Data 2021, 4, 591749. [CrossRef]

3. Emmert-Streib, F.; Yli-Harja, O.P.; Dehmer, M. Data analytics applications for streaming data from social media: What to predict? Front. Big Data 2018, 1, 2. [CrossRef] [PubMed]

4. Statista. Number of Worldwide Social Network Users. 2019. Available online: https://www.statista.com/statistics/278414 / number-of-worldwide-social-network-users / (accessed on 25 January 2021).

5. DIGITAL. Social Media statistics for Oman. 2021. Available online: https://datareportal.com/reports/digital-2021-oman (accessed on 29 May 2021).

6. Uddin, M.S.; Al Mamun, A.; Iqbal, M.A.; Nasrullah, M.; Asaduzzaman, M.; Sarwar, M.S.; Amran, M.S. Internet addiction disorder and its pathogenicity to psychological distress and depression among university students: A cross-sectional pilot study in Bangladesh. Psychology 2016, 7, 1126. [CrossRef]

7. Al-Rahmi, W.; Othman, M. The impact of social media use on academic performance among university students: A pilot study. J. Inf. Syst. Res. Innov. 2013, 4, 1-10.

8. El Khatib, D.; Khan, F.R. Implications of social media networks technology in interpersonal skills and academic performances. Int. J. Manag. Innov. Entrep. Res. EISSN 2017, 3, 99-110. [CrossRef] 
9. Nasrullah, S.; Khan, F.R. Examining the Impact of Social Media on the Academic Performances of Saudi Students-Case Study: Prince Sattam Bin Abdul Aziz Univ. Humanit. Soc. Sci. Rev. 2019, 7, 851-861. [CrossRef]

10. Chytas, D. Use of social media in anatomy education: A narrative review of the literature. Ann. Anat. Anat. Anz. 2019, 221, 165-172. [CrossRef]

11. Hashim, K.F.; Rashid, A.A.S. Social Media for Teaching and Learning within Higher Education Institution: A Bibliometric Analysis of the Literature (2008-2018). Int. J. Interact. Mob. Technol. 2018, 12, 4-19. [CrossRef]

12. Al-Rahmi, W.M.; Alias, N.; Othman, M.S.; Marin, V.I.; Tur, G. A model of factors affecting learning performance through the use of social media in Malaysian higher education. Comput. Educ. 2018, 121, 59-72. [CrossRef]

13. Price, A.M.; Devis, K.; LeMoine, G.; Crouch, S.; South, N.; Hossain, R. First year nursing students use of social media within education: Results of a survey. Nurse Educ. Today 2018, 61, 70-76. [CrossRef] [PubMed]

14. Bagarukayo, E. Social media use to transfer knowledge into practice and aid interaction in higher education. Int. J. Educ. Dev. Using ICT 2018, 14, 2.

15. Alhaddad, M.S. The use of social media among Saudi residents for medicines related information. Saudi Pharm. J. 2018, 26, 1106-1111. [CrossRef] [PubMed]

16. Duke, V.J.; Anstey, A.; Carter, S.; Gosse, N.; Hutchens, K.M.; Marsh, J.A. Social media in nurse education: Utilization and E-professionalism. Nurse Educ. Today 2017, 57, 8-13. [CrossRef] [PubMed]

17. Bal, E.; Bicen, H. The purpose of students' social media use and determining their perspectives on education. Procedia Comput. Sci. 2017, 120, 177-181. [CrossRef]

18. Tang, Y.; Hew, K.F. Using Twitter for education: Beneficial or simply a waste of time? Comput. Educ. 2017, 106, 97-118. [CrossRef]

19. Rueda, L.; Benitez, J.; Braojos, J. From traditional education technologies to student satisfaction in Management education: A theory of the role of social media applications. Inf. Manag. 2017, 54, 1059-1071. [CrossRef]

20. Ali, M.; Yaacob, R.A.I.B.R.; Bin Endut, M.N.A.-A.; Langove, N.U. Strengthening the academic usage of social media: An exploratory study. J. King Saud Univ. Comput. Inf. Sci. 2017, 29, 553-561. [CrossRef]

21. Benetoli, A.; Chen, T.F.; Aslani, P. The use of social media in pharmacy practice and education. Res. Soc. Adm. Pharm. 2015, 11, 1-46. [CrossRef] [PubMed]

22. Kitching, F.; Winbolt, M.; MacPhail, A.; Ibrahim, J. Web-based social media for professional medical education: Perspectives of senior stakeholders in the nursing home sector. Nurse Educ. Today 2015, 35, 1192-1198. [CrossRef]

23. Van Rooyen, A. Distance Education Accounting Students' Perceptions of Social Media Integration. Procedia Soc. Behav. Sci. 2015, 176, 444-450. [CrossRef]

24. Eger, L. Is Facebook a Similar Learning Tool for University Students as LMS? Procedia Soc. Behav. Sci. 2015, 203, 233-238. [CrossRef]

25. Dunn, L. Teaching in higher education: Can social media enhance the learning experience? In Proceedings of the 16th Annual Learning and Teaching Conference, Glasgow, UK, 19 April 2013.

26. Junco, R.; Heiberger, G.; Loken, E. The effect of Twitter on college student engagement and grades. J. Comput. Assist. Learn. 2010, 27, 119-132. [CrossRef]

27. Moran, M.; Seaman, J.; Tinti-Kane, H. Teaching, Learning, and Sharing: How Today's Higher Education Faculty Use Social Media; Babson Survey Research Group, Babson College: Babson Park, MA, USA, 2011.

28. George, D.R.; Dellasega, C. Use of social media in graduate-level medical humanities education: Two pilot studies from Penn State College of Medicine. Med. Teach. 2011, 33, e429-e434. [CrossRef]

29. Alshdefait, M.A.; Alzboon, M.S. Status of Utilizing Social Media Networks in the Teaching-Learning Process at Public Jordanian Universities. Arab. J. Qual. Assur. High. Educ. 2018, 11, 77-98. [CrossRef]

30. Sobaih, A.E.E.; Moustafa, M.A.; Ghandforoush, P.; Khan, M. To use or not to use? Social media in higher education in developing countries. Comput. Hum. Behav. 2016, 58, 296-305. [CrossRef]

31. Vollum, M.J. The potential for social media use in K-12 physical and health education. Comput. Hum. Behav. 2014, 35, 560-564. [CrossRef]

32. Wang, Q.; Chen, W.; Liang, Y. The effects of social media on college students. MBA Stud. Scholarsh. 2011, 5, 1-12.

33. Ghani, N.A.; Hamid, S.; Hashem, I.A.T.; Ahmed, E. Social media big data analytics: A survey. Comput. Hum. Behav. 2019, 101, 417-428. [CrossRef]

34. Willis, L.D.; Exley, B. Using an online social media space to engage parents in student learning in the early-years: Enablers and impediments. Digit. Educ. Rev. 2018, 33, 87-104. [CrossRef]

35. Alcántar, M.D.R.C. Teaching experience in university students using social networks. World J. Educ. Technol. Curr. Issues 2016, 8 , 224-230. [CrossRef]

36. Hair, J.F.; Sarstedt, M.; Ringle, C.M.; Mena, J.A. An assessment of the use of partial least squares structural equation modeling in marketing research. J. Acad. Mark. Sci. 2012, 40, 414-433. [CrossRef]

37. Tenenhaus, M.; Vinzi, V.E.; Chatelin, Y.-M.; Lauro, C. PLS path modeling. Comput. Stat. Data Anal. 2005, 48, 159-205. [CrossRef]

38. Henderson, D.; Sheetz, S.D.; Trinkle, B.S. The determinants of inter-organizational and internal in-house adoption of XBRL: A structural equation model. Int. J. Account. Inf. Syst. 2012, 13, 109-140. [CrossRef]

39. Hair, J.F.; Black, W.C.; Babin, B. Multivariate Data Analysis; Prentice Hall: Upper Saddle River, NJ, USA, 1998 ; Volume 5.

40. Comrey, A.L.; Lee, H.B. A First Course in Factor Analysis; Psychology Press: Hove, UK, 2003. 
41. Hulland, J. Use of partial least squares (PLS) in strategic management research: A review of four recent studies. Strateg. Manag. J. 1999, 20, 195-204. [CrossRef]

42. Bagozzi, R.P.; Yi, Y. On the evaluation of structural equation models. J. Acad. Mark. Sci. 1988, 16, 74-94. [CrossRef]

43. Fornell, C.; Larcker, D.F. Evaluating Structural Equation Models with Unobservable Variables and Measurement Error. J. Mark. Res. 1981, 18, 39-50. [CrossRef]

44. Huang, C.-C.; Wang, Y.-M.; Wu, T.-W.; Wang, P.-A. An Empirical Analysis of the Antecedents and Performance Consequences of Using the Moodle Platform. Int. J. Inf. Educ. Technol. 2013, 3, 217-221. [CrossRef]

45. Wixom, B.H.; Watson, H.J. An Empirical Investigation of the Factors Affecting Data Warehousing Success. MIS Q. 2001, 25, 17-41. [CrossRef] 